\title{
Package Atmosphere Affects Postharvest Biology and Quality of Fresh-cut Cilantro Leaves
}

Yaguang Luo, ${ }^{1}$ James L. McEvoy, Marian R. Wachtel, Ji Gang Kim, and Yun Huang

Produce Quality and Safety Laboratory, Beltsville Agricultural Research Center, ARS, USDA, 10300 Baltimore Avenue, Beltsville, MD 20705-2350

Additional index words. Coriandrum sativum, modified atmosphere package, electrolyte leakage, aerobic bacteria count, anaerobic bacteria count

Abstract. Experiments were conducted to develop a modified atmosphere packaging system for fresh-cut cilantro (Coriandrum sativum $\mathrm{L}$.) leaves, and to determine the effect of package film oxygen transmission rate (OTR) on package atmosphere and the consequence on quality and microbiology of the product. Package film OTR significantly $(P<0.001)$ influenced the package atmospheres and the resultant postharvest physiology and quality of fresh-cut cilantro leaves under the tested package configuration (bag size $19 \times 22 \mathrm{~cm}$, product fill weight $85 \mathrm{~g} / \mathrm{bag}$ ) and storage condition $\left(0^{\circ} \mathrm{C}\right)$. Oxygen and carbon dioxide levels of the packages prepared with $3500 \mathrm{~mL} \cdot \mathrm{d}^{-1} \cdot \mathrm{m}^{-2}$ OTR films equilibrated at 1.5 to $2.3 \mathrm{kPa}$ and 3.6 to $4.1 \mathrm{kPa}$, respectively, on day 3 and maintained this level throughout the storage. The gas compositions of the packages with $6200 \mathrm{~mL} \cdot \mathrm{d}^{-1} \cdot \mathrm{m}^{-2}$ OTR films showed a similar trend, except they equilibrated at a higher $\mathrm{O}_{2}(3.6$ to $5.6 \mathrm{kPa})$ and lower $\mathrm{CO}_{2}(2.7$ to 3.3 kPa) level. Fresh-cut cilantro leaves in both packages exhibited the highest tissue integrity as evidenced by the lowest tissue electrolyte leakage, with high overall visual quality scores (like moderately to like very much) at the end of 14 days storage. However, atmospheres in $1700 \mathrm{~mL} \cdot \mathrm{d}^{-1} \cdot \mathrm{m}^{-2}$ OTR film packages displayed a rapid depletion of $\mathrm{O}$, and accumulation of $\mathrm{CO}_{2}$, with essentially no $\mathrm{O}_{2}(\approx 0.02 \mathrm{kPa})$ and high $\mathrm{CO}_{2}(7.7$ to $9.0 \mathrm{kPa})$ levels inside the packages from day 6 until the end of storage. A rapid increase in tissue electrolyte leakage was observed in cilantro leaves in these packages starting on day 6 , increasing 6-fold at the end of the storage period. Products in these packages developed a strong off-odor, accompanied by a rapid loss of typical aroma and overall visual quality, with an unacceptable quality rating at the end of storage (dislike slightly). Samples packaged in perforated bags (without modified atmosphere) lost moisture over time, and small numbers of wilted leaves were seen. There was a slow but significant $(P<0.001)$ increase in aerobic organisms over time with no significant $(P>0.05)$ difference among treatments. There was an increase in anaerobic microorganisms on cilantro leaves packaged in $1700 \mathrm{~mL} \cdot \mathrm{d}^{-1} \cdot \mathrm{m}^{-2}$ OTR film, although only $\approx 0.5 \mathrm{log} \mathrm{cfu} / \mathrm{g}$ difference was observed among the treatments and over time.

The fresh-cut fruit and vegetable industry has been rapidly expanding during the past decade, due to the freshness and high nutrition that fresh-cut produce offers, as well as convenience to consumers (Bauer 1997; Hodge 1995; Watada et al., 1996). With the successful use of modified atmosphere packaging (MAP) systems, a wide variety of vegetables have been used successfully in the fresh-cut products, such as packaged fresh-cut iceberg and romaine lettuce (Lactuca sativa L.), carrot (Daucus carota L.), cabbage (Brassica oleracea L.), and spinach (Spinacia oleracea L.) (Bauer 1997). However, the processing and sale of packaged fresh-cut culinary herbs have had limited success. Although there is increased demand for

Received for publication 3 Aug. 2002. Accepted for publication25 June 2003. Use of a company or product name by the U.S. Department of Agriculture does not imply approval or recommendation of the product to the exclusion of others that may also be suitable. The authors wish to thank Hernando Dominguez for technical assistance. We also thank Natural Selection Foods Inc., San Juan Bautista, Calif., for in-kind support of the raw materials.

${ }^{1}$ Corresponding author. packaged fresh-cut culinary herbs at both the retail and food service sectors, the preparation of fresh-cut herbs with acceptable quality and shelf life remains a challenge due to their high perishability.

Cilantro (Coriandrum sativum L.), also called Chinese parsley or coriander, is an important fresh culinary herb in the United States, widely used in Mexican and Asian cuisines (Loaiza and Cantwell, 1997). Fresh cilantro leaves offer unique aroma, taste, and flavor (Potter and Fagerson, 1990). Studies on whole/bunched cilantro indicate that it has a moderately high respiration rate ( 15 to $20 \mu \mathrm{L}$ $\mathrm{CO}_{2} / \mathrm{g} / \mathrm{h}$ at $5{ }^{\circ} \mathrm{C}$ ), and requires $0{ }^{\circ} \mathrm{C}$ storage to maintain quality and shelf life (Loaiza and Cantwell, 1997). Major defects of cilantro during storage include leaf yellowing, decay, dehydration, and the loss of typical aroma (Cantwell and Reid, 1993). With controlled atmosphere storage, leaf yellowing of cilantro was retarded and shelf life extended under moderately low $\mathrm{O}_{2}$ and high $\mathrm{CO}_{2}$ conditions (Aharoni et al., 1989); excessively high $\mathrm{CO}_{2}(>9 \mathrm{kPa}$ ) caused physiological injury resulting in dark lesions (Loaiza and Cantwell, 1997).

The main purposes of this study were to develop a modified atmosphere packaging system for fresh-cut cilantro leaves with acceptable quality and a 14-d shelf life (required for distribution and retail sales), and to evaluate the postharvest biology and quality changes of fresh-cut cilantro leaves influenced by package atmosphere achieved via package film oxygen transmission rate.

\section{Materials and Methods}

Sample preparation. Fresh cilantro(Coriandrum sativum L.) were obtained from a commercial salad manufacturer (Natural Selection Foods Inc., San Juan Bautista, Calif.), shipped overnight at $5{ }^{\circ} \mathrm{C}$ conditions to our lab at Maryland, and processed within $3 \mathrm{~d}$ after harvesting Outer leaves and unusable stems were removed, and leaves were cut into $\approx 3-\mathrm{cm}$ segments. The cut leaves were washed and sanitized in 100 ppm chlorine solution $(\mathrm{NaOCl})$ at $\mathrm{pH} 7.0,5$ ${ }^{\circ} \mathrm{C}$, for $1 \mathrm{~min}$ in a commercial salad washer (model MPW-800 Mini Polywash; Meyer Machine Co., San Antonio, Texas) with gentle agitation. The products were then centrifuged at $300 \mathrm{rpm}$ for $2 \mathrm{~min}$ with a commercial salad centrifugal dryer (model T-304; Garroute Spin Dryer, Meyer Machine Co.) to remove excess water. Samples of $85 \mathrm{~g}$ each were packaged in sealed polypropylene bags $(19 \times 22 \mathrm{~cm})$ of selected film oxygen transmission rate(OTR) of 1700,3500 , or $6200 \mathrm{~mL} \cdot \mathrm{d}^{-1} \cdot \mathrm{m}^{-2}$, and perforated bags (film manufacturer: Package Concept Inc., Salinas, Calif.). The packages were flushed with $5 \mathrm{kPaO}$ to accelerate the gas equilibrium rate. Samples were stored at $0{ }^{\circ} \mathrm{C}$ for subsequent quality evaluation.

Respiration rate and ethylene production. Fresh (intact) and fresh-cut cilantro samples, $200 \mathrm{~g}$ each, were placed in gas-tight containers at $0{ }^{\circ} \mathrm{C}$. Ethylene and $\mathrm{CO}_{2}$ production rates were monitored for $48 \mathrm{~h}$ at a 2 -h interval using an automatic sampling, flow-through system (Watada and Massie, 1981). Data reported here were taken $12 \mathrm{~h}$ after cutting when respiration and ethylene production reached a steady state after the initial rate peak due to wound response.

Gas composition and product quality. The package atmospheric compositions were measured using an $\mathrm{O} / \mathrm{CO}_{2}$ analyzer (model Combi Check 9800-1; PBI Dansensor Inc., Denmark). The color of the leaves was measured using a chromameter (model CR-300; Minolta Corp. Osaka, Japan). The values of $\mathrm{L}^{*}, \mathrm{a}^{*}$, and $\mathrm{b}^{*}$ were directly obtained from the color meter and the hue angle was calculated according to Gnanasekharan et al. (1992) and McGuire (1992). To minimize the effect of color variations within the bags, 30 color readings were taken per bag. Sensorial quality attributes of typical aroma, off-odor, and overall quality were

Table 1. Stead state respiration and ethylene production rates of intact and fresh-cut cilantro measured $12 \mathrm{~h}$ after cutting. ${ }^{2}$

\begin{tabular}{lcc}
\hline Cilantro & $\mathrm{CO}_{2}\left(\mathrm{mg} \cdot \mathrm{kg}^{-1} \cdot \mathrm{h}^{-1}\right)$ & $\mathrm{C}_{2} \mathrm{H}_{4}\left(\mu \mathrm{L} \cdot \mathrm{kg}^{-1} \cdot \mathrm{h}^{-1}\right)$ \\
\hline Intact & $25.0 \pm 1.6$ & $1.1 \pm 0.1$
\end{tabular}

\begin{tabular}{lll} 
Intact & $25.0 \pm 1.6$ & $1.1 \pm 0.1$ \\
Fresh-cut & $35.8 \pm 3.3$ & $1.1 \pm 0.1$ \\
\hline
\end{tabular}

${ }^{2}$ Data represent the mean \pm SE of triplicate samples. 

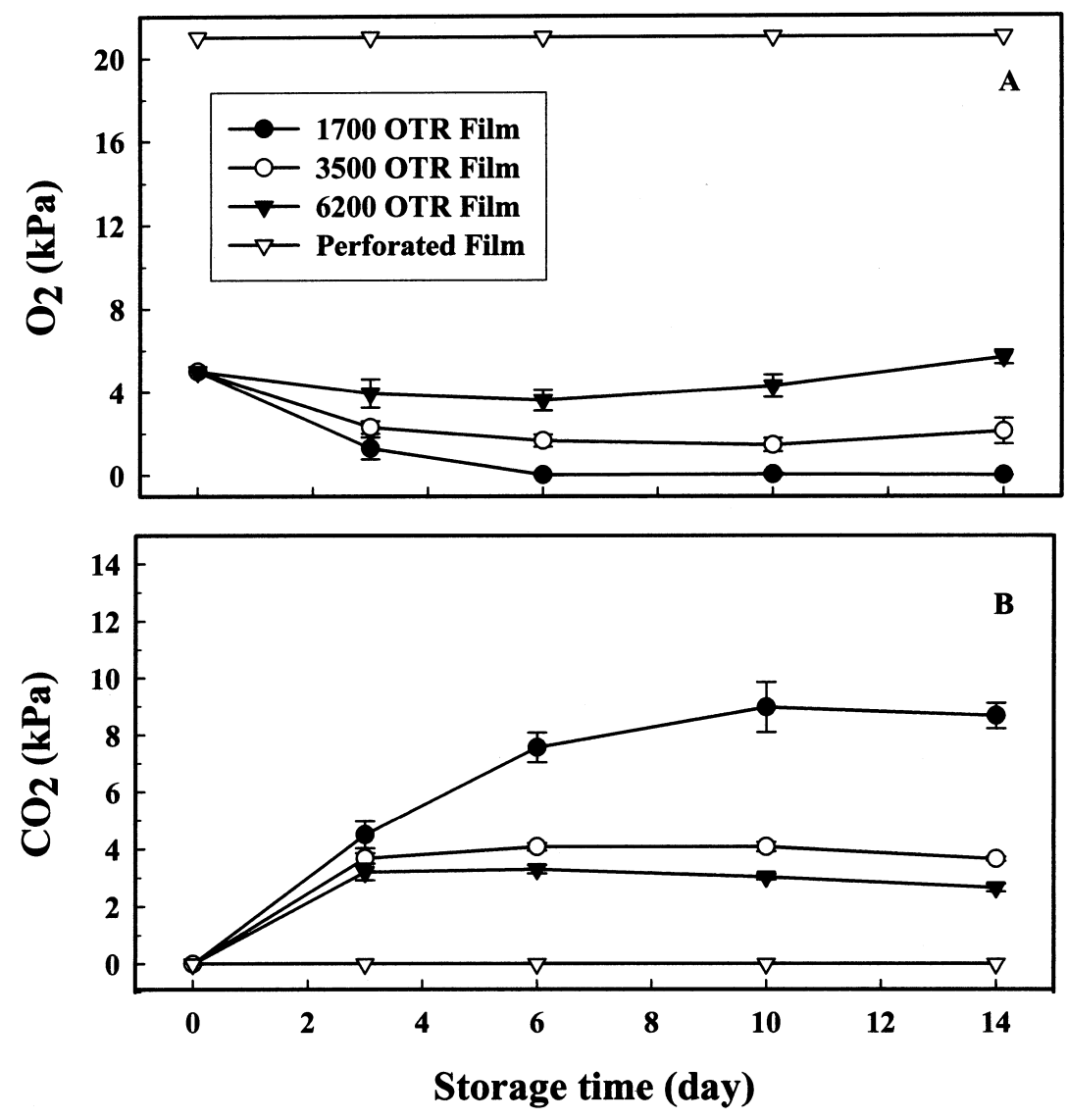

Fig. 1. Changes in gas composition of packages as influenced by film OTR, film perforation and storage time at $0{ }^{\circ} \mathrm{C}$. Vertical bars represent $\pm 1 \mathrm{SE}$ of triplicate samples. (A) $\mathrm{O}_{2}(\mathrm{kPa}),(\mathbf{B}) \mathrm{CO}_{2}(\mathrm{kPa})$

evaluated immediately after opening the bags by a three-member trained panel following a modified procedure from Loaiza and Cantwell (1997). Aroma was scored on a 5 to 1 scale where $5=$ maximum, $4=$ near typical, $3=$ moderate, $2=$ slight and $1=$ none. Off-odor was scored on a 1 to 5 scale, where $1=$ no off-odor and $5=$ extremely strong off-odor. Overall quality was evaluated with a 9-point hedonic scale, where $9=$ like extremely, $5=$ neither like nor dislike and 1 = dislike extremely (Meilgaard et al., 1991). Product moisture loss was assessed based on the weight change at the time of sampling divided by the initial weight. Product decay and damage, tissue yellowing, and wilting were determined by separating cilantro leaves showing those symptoms from the rest of the product, weighed and reported as percentage of decay and damage, wilting, and yellowing.

Electrolyte leakage. Samples of $50 \mathrm{~g}$ cilantro leaves were submerged in $500 \mathrm{ml}$ of de-ionized water for $30 \mathrm{~min}$. The electrolyte content of the solution was measured using a conductivity meter (model 135A; Orion Research Inc., Beverly, Mass.). Total electrolytes of the samples were determined after freezing the samples at $-20^{\circ} \mathrm{C}$ for $24 \mathrm{~h}$ and thawing at room temperature (Hong et al., 2000). Electrolyte leakage was expressed as a percentage of total electrolytes.

Microbial testing. Cilantro samples (30 g) were macerated for $2 \mathrm{~min}$ at $260 \mathrm{rpm}$ in 270 $\mathrm{mL}$ of $0.1 \%$ sterile peptone water, $\mathrm{pH} 7.4$, with a lab stomacher (model 400; Seward Medical, London, U.K.). The supernatants were then plates at $28{ }^{\circ} \mathrm{C}$ for $2 \mathrm{~d}$. The anaerobic plate count (AnPC) was assessed by plating on TSA medium, and incubating the plates at $28^{\circ} \mathrm{C}$ for 3 $\mathrm{d}$ anaerobically in BBLGasPak pouches (Becton Dickinson and Co., Cockeysville, Md.). Yeast and molds were cultured with potato dextrose agar (PDA, Difco Lab) with the addition of chloramphenicol $\left(200 \mu \mathrm{L} \cdot \mathrm{L}^{-1}\right)$ and incubated at $28^{\circ} \mathrm{C}$ for $3 \mathrm{~d}$. Microbial colonies were counted using a Protos Colony Counter (model 50000; Synoptics Ltd, Cambridge, U.K.) and reported as $\log \mathrm{cfu} / \mathrm{g}$ of tissue.

Experimentaldesign and statistical analysis. All quality evaluations were performed in a temperature-controlled room at $5^{\circ} \mathrm{C}$ to minimize the effect of temperature variation during testing. Treatments were arranged in a factorial design with storage time and package film type as main factors. Three replications (three bags) per treatment per evaluation period were examined. Data were analyzed for statistical significance using the Proc Mixed procedure of SAS (SAS Inst., Cary, N.C.).

\section{Results and Discussion}

Respiration rate and ethylene production. Fresh-cut preparation markedly increased the respiration rate of cilantro leaves (Table 1 ). At $0{ }^{\circ} \mathrm{C}$, the respiration rate $\left(\mathrm{CO}_{2}\right.$ production) of fresh-cut cilantro leaves was $35.8 \mathrm{mg} \cdot \mathrm{kg}^{-1} \cdot \mathrm{h}^{-1}$, compared to that of the intact at $25.0 \mathrm{mg} \cdot \mathrm{kg}^{-1} \cdot \mathrm{h}^{-1}$. There are no reports of the respiration rate of fresh-cut cilantro leaves; but the trend between fresh-cut and intact of cilantro is similar to other types of vegetable items (Watada et al., 1996). However, both fresh-cut and intact cilantro produced only small amounts of ethylene (1.1 $\mu \mathrm{L} \cdot \mathrm{kg}^{-1} \cdot \mathrm{h}^{-1}$, Table 1 ) and there was no significant

Gas composition. Package film OTR significantly $(P<0.001)$ affected the gas composition of the packages (Fig. 1). Oxygen and $\mathrm{CO}_{2}$ levels inside the 3500 OTR film bags reached equilibria of 1.5 to $2.3 \mathrm{kPa}$ and 3.6 to $4.1 \mathrm{kPa}$, respectively,

Fig. 2. The effect of package film OTR and perforation on electrolyte leakage of fresh-cut cilantro leaves

HortScience Vol. 39(3) June 2004 difference between them. aerobic plate count (APC) was determined by plating the samples on tryptic soy agar (TSA, Difco Lab, Detroit, Mich.) and incubating the

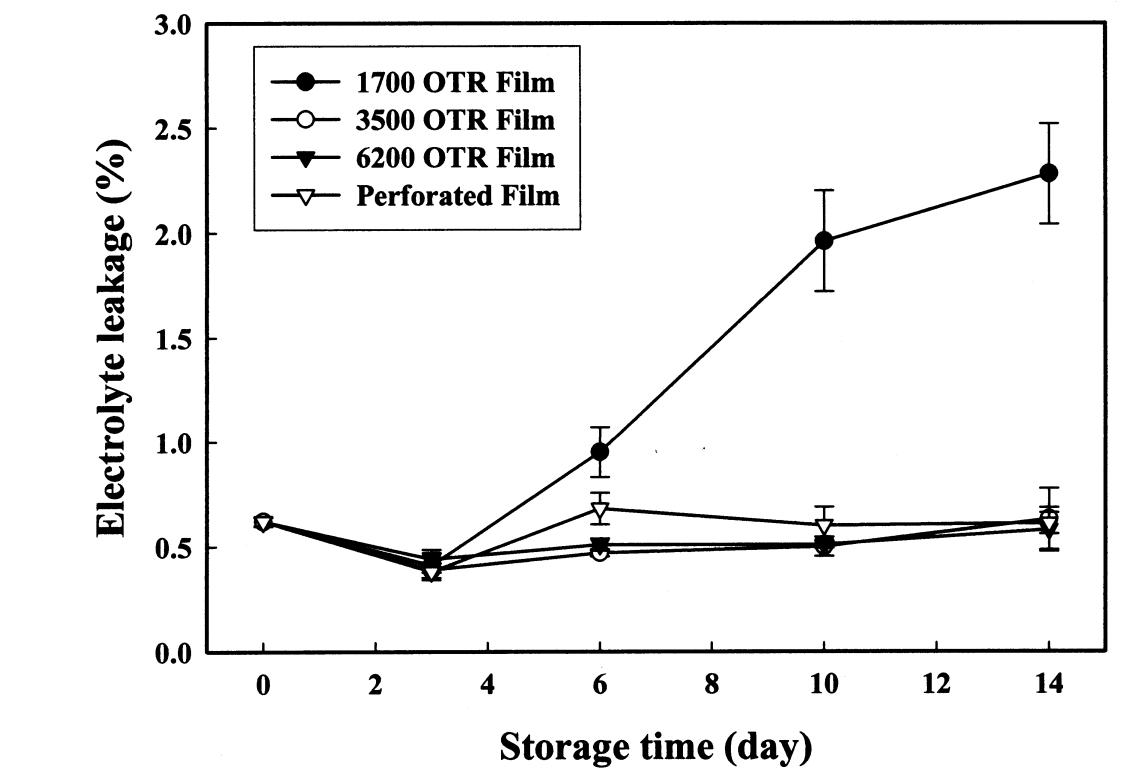

during storage at $0{ }^{\circ} \mathrm{C}$. Vertical bars represent \pm 1 SE of triplicated sample.

filtered through sterile glass wool and serially diluted with peptone water. Appropriate dilutions were spread onto selected culture media plates with a spiral plater (Autoplate model 

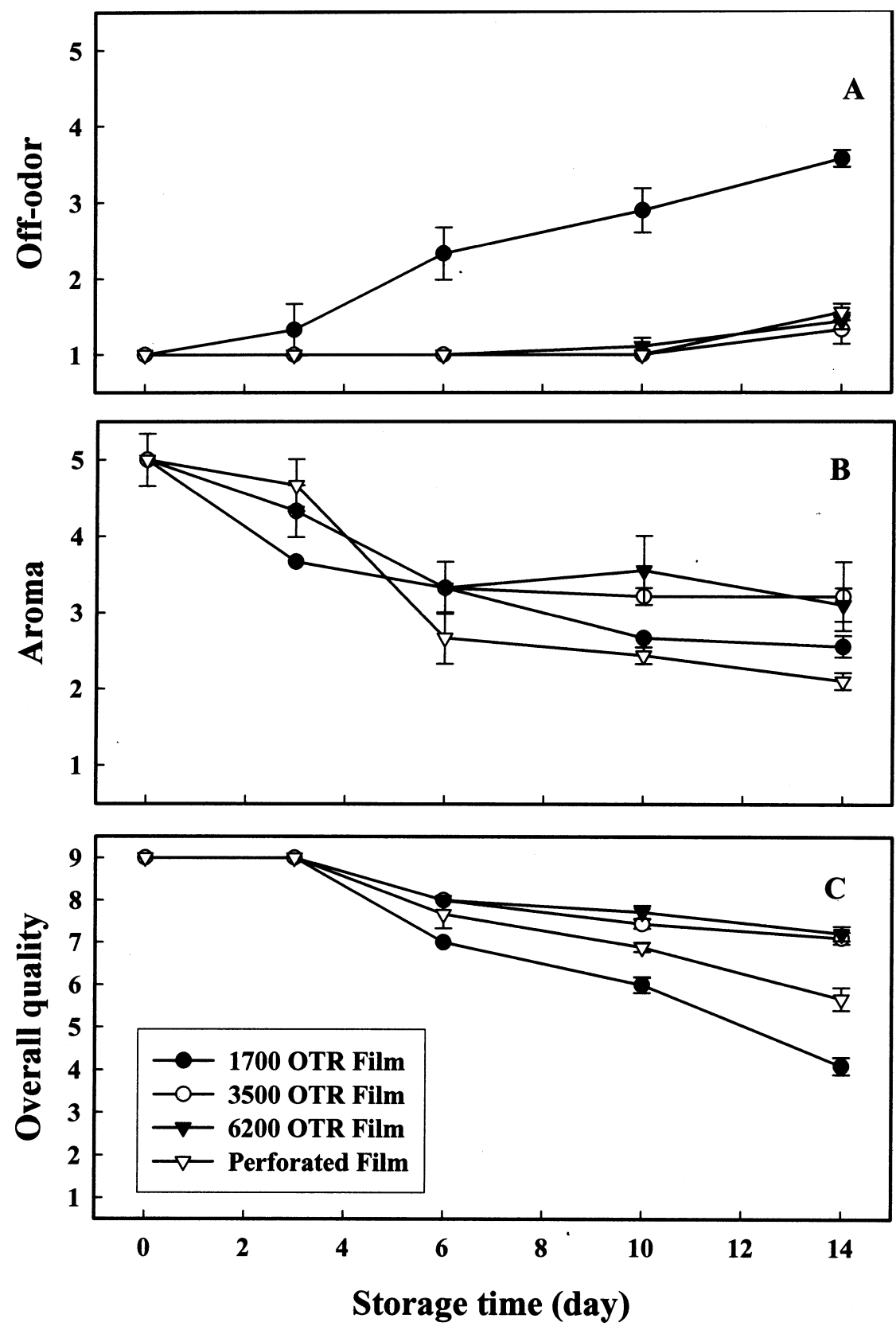

Fig. 3. The effect of package film OTR and perforation on sensorial quality of cilantro leaves during storage at $0{ }^{\circ} \mathrm{C}$. (A) Off-odor, $(\mathbf{B})$ aroma, $(\mathbf{C})$ overall quality. Vertical bars represent $\pm 1 \mathrm{SE}$ of triplicate samples.

on day 3 and maintained this level throughout 14 $\mathrm{d}$ of storage. The gas composition of the 6200 OTR film bags showed a similar trend, except they equilibrated at higher $\mathrm{O}_{2}(3.6$ to $5.6 \mathrm{kPa})$ and lower $\mathrm{CO}_{2}(2.7$ to $3.3 \mathrm{kPa})$ levels. However, packages prepared with the lowest OTR film (1700 OTR) performed differently: there was a rapid depletion of $\mathrm{O}_{2}$ and accumulation of $\mathrm{CO}_{2}$ with essentially no $\mathrm{O}_{2}(\approx 0.02 \mathrm{kPa})$ and high $\mathrm{CO}_{2}$ (7.7 to $9.0 \mathrm{kPa}$ ) inside the packages from day 6 until the end of the storage.

Electrolyte leakage. Before cutting, fresh cilantro leaves showed low electrolyte leakage, which increased dramatically after fresh-cut preparation (data not shown), probably due to rupture of cell membranes resulting in the release of tissue fluid. Interestingly, from day 0 to day 3 , there was a significant $(P<0.001)$ decrease in electrolyte leakage during cold storage among all treatments (Fig. 2). This decrease in electrolyte leakage is probably due at least in part to influx of electrolytes from cut (ruptured) cells into metabolically active (healthy) cells. Since electrolyte leakage is related to cell membrane integrity (Marangoni et al., 1996; Murata 1989), this decrease in tissue electrolyte leakage may also suggest that a membrane damage recovery process might exist during the early stage of cold storage following cutting. Studies on membrane structural lipids and the membrane ultrastructures of fresh-cut carrots also suggested the occurrence of a membrane repair process (Picchioni et al., 1994 Picchioni and Watada 1996). In this experiment, there was a significant $(P<0.001)$ increase in electrolyte leakage for samples inside the 1700 OTR film bags beginning on day 6 . Since there was a rapid depletion of $\mathrm{O}_{2}$ and accumulation of $\mathrm{CO}_{2}$ in this treatment, the rapid increase in electrolyte leakage was probably the result of cell membrane damage caused by low $\mathrm{O}_{2}$ and high $\mathrm{CO}_{2}$ injury. However, all other treatments had a very slow increase in electrolyte leakage beginning on day 6 until the end of the storage, suggesting that good cell membrane integrity of cilantro leaves was maintained under those package conditions.

Sensorial quality. A slight to moderate leve of off-odor was detected from cilantro leaves packaged in 1700 OTR film bags starting on day 6(Fig. 3A). The off-odor became very strong on day 14 , corresponding to the rapid depletion of $\mathrm{O}_{2}$ and accumulation of $\mathrm{CO}_{2}$ in those packages. Since off-odor is often associated with the onset of anaerobic respiration under low $\mathrm{O}_{2}$ and high $\mathrm{CO}_{2}$ conditions, this suggests that the low $\mathrm{O}_{2}$ and high $\mathrm{CO}_{2}$ levels inside the 1700 OTR film bags had caused anaerobic respiration of cilantro leaves. This also agrees with the electrolyte leakage results. Unlike samples in the low OTR film bags, cilantro leaves in all other treatments had no off-odor throughout day 10 , and only trace amounts of off-odor were detected at the end of storage. This indicates that there was no or only trivial anaerobic respiration due to the presence of $\mathrm{O}_{2}$ and low $\mathrm{CO}_{2}$ in those treatments. This also agrees with the low electrolyte leakage and good cell membrane integrity results found in those treatments.

There was a gradual loss of typical aroma of cilantro leaves over time (Fig. 3B). Although there was a greater loss of aromain the perforated bag treatment, the difference among all treatments was minimal. This suggests that the loss of the typical aroma of cilantro is not influenced by the package atmospheres.

With regard to overall visual quality, there was no noticeable quality decline among al treatments from day 0 to day 3 (Fig. 3C) Symptoms of some minor damage (bruises) on fresh-cut cilantro leaves observed on day 0 disappeared by day 3 . Considering the early decrease in electrolyte leakage on day 3 , this may suggest a damage recovery process at the early stage of cold storage of fresh-cut cilantro leaves. However, beginning on day 6 , there was a rapid decline in overall quality of cilantro leaves packaged in 1700 OTR film bags, mainly due to the development of off-odor and loss of the fresh appearance. At the end of storage, the overall quality scores of cilantro leaves in this

\begin{tabular}{lcccc}
\multicolumn{5}{l}{ Table 2. Quality attributes of fresh-cut cilantro leaves held at $0{ }^{\circ} \mathrm{C}$ for $14 \mathrm{~d}^{\mathrm{z}}$} \\
\hline Film & $\begin{array}{c}\text { Moisture } \\
\text { loss }(\%)\end{array}$ & $\begin{array}{c}\text { Wilting } \\
(\%)\end{array}$ & $\begin{array}{c}\text { Decay and } \\
\text { damage }(\%)\end{array}$ & $\begin{array}{c}\text { Yellowing } \\
(\%)\end{array}$ \\
type & 0 & 0 & $5.1 \pm 1.6$ & 0 \\
1700 OTR & 0 & 0 & $1.7 \pm 0.3$ & 0 \\
500 OTR & 0 & 0 & $1.3 \pm 0.3$ & $0.1 \pm 0.1$ \\
6200 OTR & $4.8 \pm 0.5$ & $1.6 \pm 1.9$ & $1.3 \pm 0.2$ & $0.2 \pm 0.2$ \\
\hline Perforated & & &
\end{tabular}

HortSCIENCE Vol. 39(2) June 2004 
Table 3. Color changes of fresh-cut cilantro leaves during storage at $0{ }^{\circ} \mathrm{C} .{ }^{\mathrm{z}}$

\begin{tabular}{|c|c|c|c|c|c|c|}
\hline \multirow{2}{*}{$\begin{array}{l}\text { Color } \\
\text { parameter }\end{array}$} & \multirow{2}{*}{$\begin{array}{l}\text { Film } \\
\text { type }\end{array}$} & \multicolumn{5}{|c|}{ Storage time $(\mathrm{d})$} \\
\hline & & 0 & 3 & 6 & 10 & 14 \\
\hline \multirow[t]{4}{*}{$\mathrm{L}^{*}$} & 1700 OTR & $48.2 \pm 0.6$ & $48.8 \pm 0.8$ & $49.4 \pm 0.5$ & $48.7 \pm 0.8$ & $48.6 \pm 0.6$ \\
\hline & 3500 OTR & $50.1 \pm 0.6$ & $50.0 \pm 0.7$ & $49.4 \pm 0.5$ & $50.4 \pm 0.5$ & $50.6 \pm 0.5$ \\
\hline & 6200 OTR & $48.7 \pm 0.8$ & $49.8 \pm 0.6$ & $50.7 \pm 0.6$ & $50.6 \pm 0.8$ & $50.1 \pm 0.6$ \\
\hline & Perforated & $48.9 \pm 0.7$ & $52.0 \pm 0.5$ & $50.6 \pm 0.7$ & $51.0 \pm 0.6$ & $51.3 \pm 0.6$ \\
\hline \multirow[t]{4}{*}{$a^{*}$} & 1700 OTR & $-8.2 \pm 0.3$ & $-8.7 \pm 0.3$ & $-8.7 \pm 0.2$ & $-8.6 \pm 0.2$ & $-8.4 \pm 0.2$ \\
\hline & 500 OTR & $-8.4 \pm 0.2$ & $-8.7 \pm 0.3$ & $-8.3 \pm 0.2$ & $-8.6 \pm 0.2$ & $-8.6 \pm 0.2$ \\
\hline & 6200 OTR & $-8.8 \pm 0.2$ & $-9.0 \pm 0.2$ & $-9.1 \pm 0.2$ & $-9.2 \pm 0.2$ & $-8.9 \pm 0.2$ \\
\hline & Perforated & $-8.0 \pm 0.2$ & $-8.7 \pm 0.2$ & $-8.3 \pm 0.2$ & $-8.6 \pm 0.2$ & $-8.8 \pm 0.2$ \\
\hline \multirow[t]{4}{*}{$\mathrm{b}^{*}$} & 1700 OTR & $11.1 \pm 0.3$ & $11.9 \pm 0.5$ & $11.9 \pm 0.3$ & $11.4 \pm 0.4$ & $11.4 \pm 0.4$ \\
\hline & 3500 OTR & $10.9 \pm 0.4$ & $11.4 \pm 0.6$ & $10.8 \pm 0.3$ & $11.1 \pm 0.4$ & $10.9 \pm 0.5$ \\
\hline & 6200 OTR & $11.8 \pm 0.4$ & $12.5 \pm 0.4$ & $12.3 \pm 0.3$ & $12.4 \pm 0.5$ & $11.9 \pm 0.4$ \\
\hline & Perforated & $10.5 \pm 0.4$ & $11.6 \pm 0.4$ & $11.2 \pm 0.6$ & $11.3 \pm 0.4$ & $11.1 \pm 0.4$ \\
\hline \multirow[t]{4}{*}{ Hue } & 1700 OTR & $-4.7 \pm 0.8$ & $-4.9 \pm 0.5$ & $-4.7 \pm 0.5$ & $-4.0 \pm 0.4$ & $-4.6 \pm 0.5$ \\
\hline & 3500 OTR & $-3.5 \pm 0.6$ & $-3.9 \pm 0.7$ & $-3.5 \pm 0.6$ & $-3.4 \pm 0.5$ & $-3.2 \pm 0.9$ \\
\hline & 6200 OTR & $-4.3 \pm 0.5$ & $-5.3 \pm 0.5$ & $-4.7 \pm 0.6$ & $-4.7 \pm 0.6$ & $-4.2 \pm 0.5$ \\
\hline & Perforated & $-3.7 \pm 0.6$ & $-4.2 \pm 0.5$ & $-4.3 \pm 0.5$ & $-3.9 \pm 0.5$ & $-3.2 \pm 0.6$ \\
\hline
\end{tabular}

Table 4. Effect of packaging film and storage time on the changes of microflora (log cfu) of fresh-cut cilantro leaves held at $0{ }^{\circ} \mathrm{C} .{ }^{2}$

\begin{tabular}{llccccc}
\hline & Film & \multicolumn{5}{c}{ Storage time $(\mathrm{d})$} \\
\cline { 3 - 7 } & type & 0 & 3 & 6 & 10 & 14 \\
\hline APC & 1700 OTR & $7.3 \pm 0.4$ & $7.5 \pm 0.1$ & $7.8 \pm 0.1$ & $8.1 \pm 0.1$ & $8.4 \pm 0.2$ \\
& 3500 OTR & & $7.5 \pm 0.1$ & $7.9 \pm 0.1$ & $8.0 \pm 0.1$ & $8.2 \pm 0.2$ \\
& 6200 OTR & & $7.7 \pm 0.1$ & $7.8 \pm 0.1$ & $8.3 \pm 0.1$ & $8.5 \pm 0.1$ \\
& Perforated & & $7.4 \pm 0.2$ & $7.6 \pm 0.1$ & $8.1 \pm 0.1$ & $8.5 \pm 0.1$ \\
AnPC & 1700 OTR & $5.4 \pm 0.2$ & $5.6 \pm 0.1$ & $6.0 \pm 0.1$ & $6.2 \pm 0.1$ & $6.6 \pm 0.1$ \\
& 3500 OTR & & $5.3 \pm 0.1$ & $5.4 \pm 0.1$ & $5.7 \pm 0.2$ & $6.0 \pm 0.1$ \\
& 6200 OTR & & $5.6 \pm 0.1$ & $5.3 \pm 0.4$ & $6.1 \pm 0.1$ & $6.0 \pm 0.1$ \\
& Perforated & & $5.7 \pm 0.2$ & $5.5 \pm 0.1$ & $6.0 \pm 0.2$ & $6.1 \pm 0.1$ \\
\hline
\end{tabular}

${ }^{2}$ Data represent mean \pm SE of triplicate samples.

treatment decreased to 4.1 , an unacceptable rating. There were small amounts of decayed leaves in this treatment (Table 2). In contrast, there was only a slight decline in overall quality of cilantro leaves packaged in 3500 or 6200 OTR film bags after $6 \mathrm{~d}$ in storage. At the end of $14 \mathrm{~d}$ storage, the overall quality of samples from those treatments were scored at 7.1 to 7.2 representing a "like strongly" to "like moderately" rating. These cilantro leaves appeared to be near the fresh, initial condition with green, fresh appearance, no yellowing or dehydration, and trace off-odor. Cilantro leaves packaged in the perforated bags (control) had a faster decline in overall quality than those packaged in 3500 or 6200 OTR films, but less than those in 1700 OTR film bags. At the end of storage, cilantro in perforated bags was rated as 5.7, representing "neither like nor dislike" to "like slightly". The loss of quality of products in perforated bags was mainly due to the loss of moisture and fresh appearance, and the presence of wilted cilantro leaves, in addition to a small amount of yellow leaves (Table 2).

Color. The changes in color, as measured by $\mathrm{L}^{*}, \mathrm{a}^{*}, \mathrm{~b}^{*}$, and hue angle values, of fresh-cut cilantro leaves were insignificant $(P>0.05)$ over time and among treatments (Table 3 ), although there was a slightly larger difference in $\mathrm{L}^{*}$ and hue angle values of cilantro leaves packaged in perforated bags between day 0 and day 14. The minimal changes in color are probably due to the low temperature storage slowing down the degradation of chlorophyll, the major pigment of cilantro leaves. Similar findings were also reported for bunched cilantro stored at $0{ }^{\circ} \mathrm{C}$ (Loaiza and Cantwell 1997).
Microbial changes. Cilantro is a low-growing vegetable crop, and the initial aerobic plate count (APC) was relatively high (Table 4), similar to that of spinach (Babic and Watada 1996), and higher than other fresh-cut vegetables (Garg et al., 1990; Magnuson et al., 1990). During storage at $0{ }^{\circ} \mathrm{C}$, there was a slow, but significant $(P<0.001)$ increase in APC over time, suggesting that the aerobic bacteria on fresh-cut cilantro grew slowly during $0{ }^{\circ} \mathrm{C}$ storage. Although there was a sigall four treatments, there was no significant difference in APC among treatments $(P>$ $0.05)$, suggesting that gas composition under the testing conditions did not influence the overall growth of aerobic bacteria of fresh-cut cilantro leaves. Beuchat and Brackett (1991) found similar results with sliced tomatoes. Anaerobic plate counts (AnPC), however, showed a slightly different trend from APC. There was a slightly, yet significantly $(P<$ $0.001)$, higher number of AnPC in samples packaged in 1700 OTR film bags starting on day 6 when the packages had depleted $\mathrm{O}_{2}$ and accumulated $\mathrm{CO}_{2}$. This difference was maintained from day 6 throughout the storage. Yeasts and molds (Y\&M) were present on fresh-cut cilantro leaves in very low numbers (data not shown) and there was no significant difference among all four treatments or storage duration, suggesting that the growth of $\mathrm{Y} \& \mathrm{M}$ on cilantro was not affected by the test gas compositions, and had little or no effect on the quality loss seen in packaged cilantro. Similar findings were reported for fresh-cut spinach (Babic and Watada, 1996). nificant difference in gas composition among

\section{Conclusions}

Package film OTR had a significant impact on the gas composition of the packages of freshcut cilantroleaves, and consequently affected the quality and microbiology of fresh-cut cilantro leaves. With the tested package configurations, packages prepared with 3500 and 6200 OTR films maintained a beneficial package atmosphere condition ( 1.5 to $5.6 \mathrm{kPa} \mathrm{O}, 2.7$ to 4.1 $\mathrm{kPaCO}_{2}$ ) and maintained acceptable quality of fresh-cut cilantroleaves. Other treatments either had rapidly depleted $\mathrm{O}_{2}$ and accumulated $\mathrm{CO}_{2}$, resulting in the development of an off-odor and loss of quality (1700 OTR film bags) or failed to maintain the moisture and color of the fresh-cut cilantro leaves (perforated bags)

\section{Literature Cited}

Aharoni, N., A. Reuveni, and O. Dvir. 1989. Modified atmospheres in film packages delay senescence and decay of fresh herbs. Acta Hort. 258:255-262.

Babic, I. and A.E. Watada. 1996. Microbial populations of fresh-cut spinach leaves affected by controlled atmosphere. Postharvest Biol. Technol. 9:187-193.

Bauer, S. 1997. Demand for fresh fruits and veggies are exploding the fresh-cut product market. Agr. Res. (Jan.):20-21.

Beuchat, L.R. and R.E. Brackett. 1991. Behavior of Listeria monocytogens inoculated into raw and processed tomato products. Appl. Env. Microbiol. 57:1367-1371.

Cantwell, M. and M.S. Reid. 1993. Postharvest physiology and handling of fresh culinary herbs. J. Herbs Spices Med. Pl. 1:93-127.

Garg, N., J.J. Churey, and F. Splittstoesser. 1990. Effect of processing conditions on the microflora of fresh-cut vegetables. J. Food Prot. 53:701-703.

Gnanasekharan, V., R.L. Shewfelt, and M.S. Chinnan. 1992. Detection of color changes in green vegetables. J. Food Sci. 57:149-554.

Hodge, K. 1995. Fresh-cut and the "perfect meal." Freshcut $3: 12,14,20$

Hong, J.H., D.J. Mills, C.B. Coffman, J.D. Anderson, M.J. Camp, and K.C. Gross. 2000. Tomato cultivation systems affect subsequent quality of fresh-cut fruit slices. J. Amer. Soc. Hort. Sci. 125:729-735.

Loaiza, J. and M. Cantwell. 1997. Postharvest physiology and quality of cilantro (Coriandrum sativum L.) HortScience 32:104-107.

Magnuson, J.A., A.D. King, and T. Torok. 1990. Microflora of partially processed lettuce. Appl. Environ. Microbiol. 56:3851-3854.

Marangoni,A.G.,T.Palma, andD.W.Stanley. 1996. Membrane effects in postharvest physiology. Postharvest Biol. Technol. 7:193-217.

McGuire, R.G. 1992. Reporting of objective colormeasurements. HortScience 27:1254-1255.

Meilgaard, M., G.V. Civille, and B.T. Carr. 1991. Sensory evaluation techniques. $2^{\text {nd }}$ ed. CRC Press, Boca Raton, Fla.

Murata, T. 1989. Relation of chilling stress to membrane permeability, p. 201-209. In: C.Y. Wang (eds.). Chilling injury of horticultural crops. CRC Press, Boca Raton, Fla.

Picchioni, G.A., A.E. Watada, S. Roy, B.D. Whitaker, and W.P. Wergin. 1994. Membrane lipid metabolism, cell permeability, and ultra structural changes in lightly processed carrots. J. Food Sci. 59:597-601.

Picchioni, G.A. and A.E. Watada. 1996. Membrane structural lipid changes in fresh-cut carrots: revisiting the "wounding and aging" phenomenon. Acta Hort. 237-242.

Potter, T.L. and S. Fagerson. 1990. Composition of coriander leaf volatile. J. Agr. Food Chem. 38:2054-2056.

Watada, A. E., N.P. Ko, and D.A. Minott. 1996. Factors affecting quality of fresh-cut horticultural products. Postharvest Biol. Technol. 9:115-125.

Watada,A.E. and D.R. Massie. 1981.A compact automatic system for measuring $\mathrm{CO}_{2}$ and $\mathrm{C}_{2} \mathrm{H}_{4}$ evolution by harvested horticultural crops. HortScience 16:39-41. 